\title{
Building a new world for the 21st century... together
}

Written by: Anne-Lise Prigent, OECD Observer

Last update: 29 January 2020

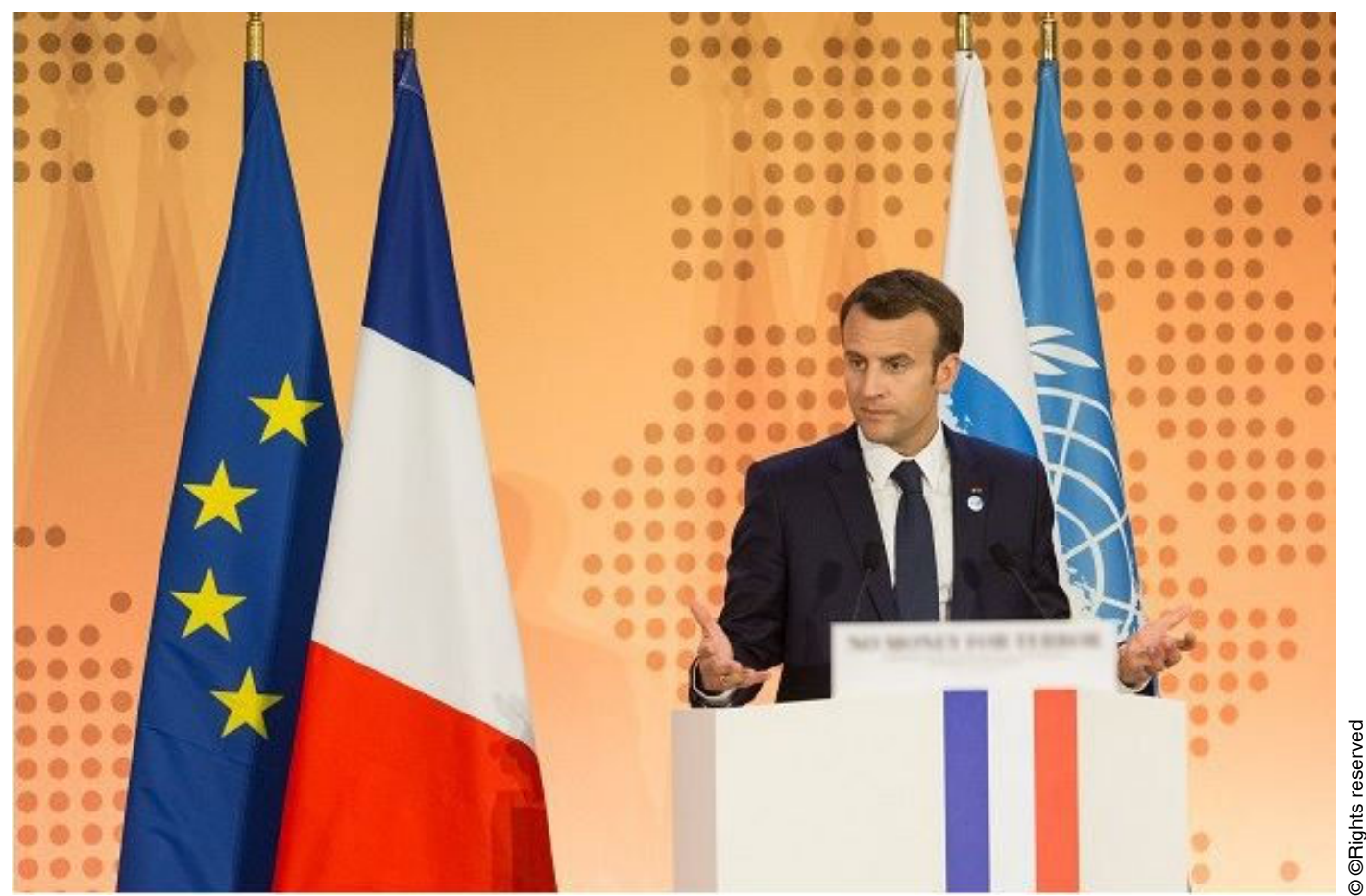

Our world seems to be at a crossroads, and with it, the multilateralism that has been the bedrock of international cooperation since the Second World War. Where do we stand? How do we move forward? The latest international discussions provide some answers.

"I have a rendezvous with Death." In his address to the US Congress in April of this year, French president Emmanuel Macron quoted these words from the young American poet, Alan Seeger. The year was 1916 and Seeger had signed up for the French Foreign Legion. He was to die, for France and for freedom. Almost 20 million deaths later, this First World War would finally come to an end. Another would follow some 20 years later, claiming 50 to 70 million lives.

It is not by chance that President Macron makes a reference to Alan Seeger. In evoking the battles that have been fought for freedom and democracy, he also spoke of the risks of our time. 
A fundamental pillar of freedom and peace, the multilateral system was created by the United States, Emmanuel Macron reminded Congress. Since the end of the Second World War, this multilateralism has been the driving force behind the development of international co-operation.

But as economic, social and environmental challenges mount, the will to cooperate is weakening. Our common goods and our shared values are under attack. The temptations of withdrawal, isolationism and nationalism are gaining ground.

And yet, multilateralism is the only way to collectively take on global problems like climate change, tax justice, pandemics, migration and a host of other issues. OECD Secretary-General Angel Gurría reminds us that the inventor of penicillin, Alexander Fleming, highlighted that "the more complex the world becomes, the more difficult it is to complete something without the co-operation of others".

"The only thing we have to fear is fear itself," recalled Mr Macron in his speech, quoting Franklin D. Roosevelt. In other words, fear solves nothing and dissipates neither the danger nor the tectonic mutations of our age. Faced with the complex global challenges of our times-challenges that our forebears could never have imagined, as Emmanuel Macron points out-we have no choice but to take them on.

We need to redesign the way in which we co-operate in order to build a new world for the 21st century. In the spirit of multilateralism, we must listen to each other and move forward together. At a time when many feel betrayed by their elitesespecially since the 2008 crisis-many citizens no longer believe in these multilateral approaches. As Mr Gurría remarks, we need to reshape and strengthen multilateral institutions. We need to make globalisation work for everybody and for our planet. Our common action must deliver more tangible results to our societies.

The OECD provides a compelling model of co-operation. The OECD's Anti-Bribery Convention has shone a spotlight on the bribery of foreign officials, making it a punishable offence in the 43 member countries who have ratified it. A recent estimate by the IMF and World Bank put the annual cost of bribery alone at about $\$ 1.5$ to $\$ 2$ trillion-roughly $2 \%$ of global GDP. In education, the OECD's Programme for International Student Assessment (PISA) enables 72 countries to learn best practices from each other. The OECD's guiding principles on responsible business conduct sets out ethical standards for multinational corporations to adhere to in its global supply chains.

In the OECD's fight against tax evasion, some $€ 85$ billion in additional tax revenue has so far been restored to governments thanks to the automatic exchange of information. During the OECD's Ministerial Council Meeting on multilateralism at the end of May, President Macron highlighted the OECD/G20 Base Erosion Profit Shifting (BEPS) project. Signed on to by more than 100 countries and territories, the BEPS initiative against the aggressive tax planning and avoidance of 
multinational corporations is an "unprecedented breakthrough against practices related to fiscal activity transfer". "Hampering the unique collective momentum created by the BEPS project would be unforgivable," Mr Macron warned.

The OECD also robustly supports the crucial multilateral initiatives spearheaded by the United Nations, namely the 2015 Paris Agreement on climate change and the 17 Sustainable Development Goals which came into effect in 2016-these are enormously significant milestones for present and future generations.

Yes, globalisation has unleashed forces that are shaking the very ground beneath our feet. The tectonic shifts are violent and multilateralism may no longer seem to be the shared bedrock we thought it to be, sustaining and binding us together. But, if we can reinvent it, multilateralism can still be the best way forward, a mighty tool, a catalyser of ideas and good practices, cultivating international dialogue and co-operation in an interdependent world.

What it should not be is "a comfortable sport, a game for sitting diplomats". Mr Macron urges us to "step out of our offices... to seek other energies". Make multilateralism more participatory, more representative and better rooted at local and regional levels, says Professor Laurence Boisson de Chazournes. It must transcend borders and represent communities of values and interest.

We can reshape multilateralism by pursuing and broadening conversations at every level. Not only with civil society, non-governmental organisations, the private sector, workers, and discussion groups, but also with those whose voices are still too often left unheard because of their age, their gender or their background. Lastly, multilateralism also means, as Mr Macron reminds us, helping the developing parts of the world. For if we ignore the cracks and inequalities of this world, they will come back to haunt us.

Our century's proliferating global problems require new identity-shaping narratives, and a new form of co-operation at the global scale, stresses Dennis J. Snower. "Global problem-solving will require new skills to manage far-flung cooperation. But there is no reason to doubt that we are capable of acquiring them." It was only 200 years ago, he points out, that humanity embarked on the process of achieving mass literacy. Without this, narratives of national co-operation could not have spread as fast and widely as they did. We need to protect global public goods and the global commons. We need to forge a new, global co-operative compact. It won't be easy. But institutions such as the G20, he argues, could play a key role in this.

Let's do it—so that the Alan Seegers of tomorrow have a rendezvous with life.

๑OOECD Observer Q3 2018

\section{References}

Emmanuel Macron - Ministerial Council Meeting Keynote Speech 
OECD Forum 2018, 29-30 May (under the auspices of France)

Gurría A. (2018), "Multilateralism Is the Only Way Forward”, Project Syndicate

Gurría A. (2018), "La coopération internationale est le plus sûr moyen de construire des politiques meilleures pour une vie meilleure", L'Observateur de l'OCDE, Paris

French Ministry of Foreign Affairs and International Development, Le multilatéralisme peut-il encore préserver la paix? (Can multilateralism still preserve peace?)

Ansley R. (2017), “Making the Case for Mutilateralism”, Atlantic Council 